\title{
The effect of bioproducts on organically grown winter wheat
}

\author{
Jolanta Sinkevičienè, \\ Juozas Pekarskas \\ Vytautas Magnus University \\ Agriculture Academy, \\ Studentu St. 11, 53361 Akademija, \\ Kaunas District, Lithuania \\ Email: jolanta.sinkeviciene@vdu.lt
}

\begin{abstract}
The study was aimed to examine the effect of the bioproducts Biokal 01 and Fitokondi on the germination of organically grown winter wheat (Triticum aestivum L.) cultivar 'Širvinta 1' seed and its contamination with microscopic fungi as well as the impact on the occurrence of foliar diseases, plant biometric indicators and grain quality. Laboratory analyses showed that the tested bioproducts did not exert any significant effect on seed vigour and germination. Fitokondi gave the highest efficacy against pathogens of seeds, its biological efficacy against Fusarium and Alternaria spp. fungi was $50.0 \%$ and against Penicillium spp. it was $20.0 \%$. Biokal 01 statistically significantly reduced only grain contamination with Mucor spp. and Aspergillus spp. The bioproducts significantly decreased the incidence of crown rot diseases in the coleoptiles of wheat seedlings and roots. In the field conditions, the bioproducts did not have any significant effect on the incidence of Septoria leaf blotch (Mycosphaerella graminicola (Fuckel) J. Schröt. anamorph Zymoseptoria tritici (Desm.) Quaedvlieg \& Crous) and tan spot (Helminthosporium tritici-repentis Died.). A significant increase in plant height and ear length, grain number per ear and 1000 grain weight was recorded. Grain yield increased by $0.66-0.79 \mathrm{t} \mathrm{ha}^{-1}$ or $18.64-22.32 \%$, as well as protein, wet gluten and dry gluten content in response to both bioproducts.
\end{abstract}

Keywords: wheat, bioproducts, organic farming, fungi, yield

\section{INTRODUCTION}

Organic production farms face two major challenges of securing nutrient supply for crops and controlling plant diseases, since the use of fertilizers and crop protection products is strictly limited by the EU regulations (Finch et al., 2006). Compared with intensive farming, considerably lower yields are produced in the organic cropping system because of the stringent requirements that organic farms have to abide by, one of which is a ban on the use of synthetic fertilizers and pesti- cides. As a result, it is vital to search for adequate alternative solutions to plant nutrient supply and disease control problems (Pekarskas, 2008).

The research done in Lithuania suggests that the grain yield and quality of organically grown winter wheat depends not only on the cultivar grown and organic fertilization applied but also on the application of liquid bioproducts and growth promoters (Sliesaravičius et al., 2006; Pekarskas, 2008). Higher crop yield requires more nutrients which can be spray-applied with foliar fertilizers. Foliar fertilization reduces nutrient shortage 
at critical moments for plants, including adverse climate, soil and other stress-induced conditions (Budzynski et al., 2003; Knittel, Albert, 2003). Bioactive substances promote crop growth and consequently enhance the competitive ability of crop plants against weeds, which is very important in organic crop production (Bond et al., 2001).

Diseases in organically grown winter wheat crops are becoming an increasingly pressing problem. Various foliar diseases occur in winter wheat crops annually; however, their severity differs between years. Septoria leaf blotch (Mycosphaerella graminicola (Fuckel) J. Schröt. anamorph Zymoseptoria tritici (Desm.)) and tan spot (Helminthosporium tritici-repentis Died.), caused by necrotrophic pathogens, is important, difficult to control winter wheat diseases, inflicting severe damage to crops (Bhathal et al., 2002). Due to the decreased plant assimilating surface and prematurely withered leaves, wheat grains grow small in size and exhibit poor quality indicators (Gaurilčikienè et al., 2008). Research has shown that bioproducts, used for crop nutrition during the growing season, can be also used for pre-sowing treatment of cereal seeds since they not only supply plants with nutrients but also reduce seed contamination with microscopic fungi and bacteria of some pathogenic genera (Pekarskas, 2008). Biologically active substances of various plant extracts and essential oils present in the bioproducts can act as biofungicides influencing the spread of fungal diseases (Fawzi et al., 2009; Al-Askar, Rashad, 2010).

The range of solid and liquid fertilizers, growth promoters currently available for use in organic farms, is rather wide; however, these products are little investigated and their effects are not completely clear. A very limited choice of biological plant protection products is one of the reasons restricting an effective control of harmful organisms in organic farms. The relevance of the problem prompts a search for alternative means intended for disease control and plant nutrient supply.

The current study was aimed to investigate the effect of the bioproducts Biokal 01 and Fitokondi on winter wheat seed germination and contamination with microscopic fungi, on the occurrence of fungal diseases in the wheat crop, as well as the impact on plant biometric indicators and grain quality.

\section{MATERIALS AND METHODS}

The research was done during 2014-2015 at the Research Laboratory of the Institute of Biology and Plant Biotechnology, Faculty of Agronomy, VMU Agriculture Academy, and on an organic farm of the Experimental Station in Kazliškiai Village $\left(54^{\circ} 52^{\prime} \mathrm{N}, 23^{\circ} 51^{\prime} \mathrm{E}\right)$. The experiments involved the winter wheat cultivar 'Širvinta 1' and were aimed to investigate the effects of the bioproducts Biokal 01 and Fitokondi on seed germination, contamination with microscopic fungi, as well as on the occurrence of foliar diseases during the growing season, plant biometric indicators, weed incidence and grain yield quality.

\section{Laboratory experiments}

Winter wheat seed samples, consisting of $200 \mathrm{~g}$ per sample, were treated with a seed treater Maxim Star 025 FS (fludioxonil $18.75 \mathrm{~g} \mathrm{l}^{-1}$ and cyproconazole $6.25 \mathrm{~g} \mathrm{l}^{-1}$ ) at a dose rate of $1.0 \mathrm{l} \mathrm{t}^{-1}$ and with the bioproducts Biokal $01\left(10 \mathrm{lt} \mathrm{t}^{-1}\right)$ and Fitokondi $\left(6 \mathrm{l} \mathrm{t}^{-1}\right)$. Biokal 01 contains 57\% medicinal herb extracts (Urtica dioicia L., Equisetum arvense L. and Chelidonium majus L.), 38\% bio-humus extract, and 5\% essential oils and mineral water. The chemical composition of Biokal 01 is the following: $\mathrm{N}-230.0 \mathrm{mg} \mathrm{l}^{-1}, \mathrm{P}_{2} \mathrm{O}_{5}-370.0 \mathrm{mg} \mathrm{l}^{-1}$, $\mathrm{K}_{2} \mathrm{O}-480.0 \mathrm{mg} \mathrm{l}^{-1}, \mathrm{Ca}-110.0 \mathrm{mg} \mathrm{l}^{-1}$, $\mathrm{Mg}-30.0 \mathrm{mg} \mathrm{l}^{-1}$, Co - $50.0 \mathrm{mg} \mathrm{l}^{-1}, \mathrm{Cu}-100 \mathrm{mg} \mathrm{l}^{-1}$ and $\mathrm{Se}-5.0 \mathrm{mg} \mathrm{l}^{-1}$. Fitokondi contains $80 \%$ water extract of medicinal herbs (Urtica dioica L., Symphytum officinale L., Quercus imbricaria bark, Equisetum arvense L., Artemisia absinthium L., Tagetes and Chelidonium majus L.) and $13.3 \%$ bio-humus extract, $6.6 \%$ potassium soap $\left(50.0 \mathrm{ml} \mathrm{l}^{-1}\right)$ and $0.1 \%$ essential oils (eucalyptus oil - $1.5 \mathrm{ml} \mathrm{l}^{-1}$ ). The chemical composition of Fitokondi is the following: $\mathrm{N}-20.0 \mathrm{mgl}^{-1}, \mathrm{P}_{2} \mathrm{O}_{5}-10.0 \mathrm{mg} \mathrm{l}^{-1}, \mathrm{~K}_{2} \mathrm{O}-150.0 \mathrm{mgl}^{-1}$, $\mathrm{Ca}-20.0 \mathrm{mg} \mathrm{l}^{-1}, \mathrm{Mg}-10.0 \mathrm{mg} \mathrm{l}^{-1}$, Co - $50.0 \mathrm{mg} \mathrm{l}^{-1}$, $\mathrm{Cu}-100 \mathrm{mg} \mathrm{l}^{-1}$ and Se $5.0 \mathrm{mg} \mathrm{l}^{-1}$ (Pekarskas, 2008).

Four 100-seed samples were collected from each experimental treatment for the determination of seed vigour and germination. Winter wheat seeds were germinated in the dark in Petri dishes on wet filter paper at $8-12^{\circ} \mathrm{C}$ for $3-4$ days, later at $20^{\circ} \mathrm{C}$. Seed vigour was established after 3 days and germination after 7 days.

The incidence of the causal agents of crown and root rots in the coleoptiles of wheat seedlings and 
roots, and seed contamination were determined by the filter paper roll method. Each experimental treatment was replicated four times on a 50 -seed sample per replication. The seeds were incubated in wet rolls for 21 days at $20^{\circ} \mathrm{C}$ temperature, at the $16 \mathrm{~h}$-day and $8 \mathrm{~h}$-night regime. Root and crown rot incidence on seedlings was estimated in points ( 0 - all seeds healthy, 1 - weakly, 2 - moderately, 3 - heavily affected) and disease severity index \% was calculated.

The effect of different products (Biokal 01, Fitokondi and Maxim Star 025 FS) on wheat seed surface contamination with microscopic fungi was determined by the Potato dextrose agar (PDA) medium (Mathur, Kongsdal, 2003). Mycological tests on 50-seed samples from each experimental treatment were replicated four times. The seeds were incubated in a thermostat at $24 \pm 2^{\circ} \mathrm{C}$ temperature. Fungal colonies were identified on the 7 th day of their development. Generic composition of fungi was identified on the basis of Leslie, Summerell (2006), Satton et al. (2001) descriptors.

\section{Field experiments}

The soil of the experimental site is Eutric Planosol - PLe-gln - $w$, with a $\mathrm{pH}$ close to neutral (6.66.9), moderate in humus (2.3\%), phosphorus (145.5 $\left.\mathrm{P}_{2} 0_{5} \mathrm{mg} \mathrm{kg}^{-1}\right)$ and potassium $\left(126.3 \mathrm{~K}_{2} 0 \mathrm{mg} \mathrm{kg}^{-1}\right)$, total $\mathrm{N} 0.2 \%$.

The field experiments involved four replications on the winter wheat cultivar 'Širvinta 1'. The total area of the experimental plot was $21 \mathrm{~m}^{2}$ and that of the harvested plot $11.0 \mathrm{~m}^{2}$. The plots were laid out in a randomised order. The pre-crop of winter wheat in 2014-2015 was oat-pea mixture for seeds.

The experiment included the following treatments: 1) control (not sprayed with the bioproducts), 2) Biokal 01 treated seeds and sprayed at a rate of $101 \mathrm{ha}^{-1}, 3$ ) Fitokondi treated seeds and sprayed at a rate of $61 \mathrm{ha}^{-1}$.

Winter wheat was sprayed at tillering $(\mathrm{BBCH} 20)$, booting (BBCH 35-38) and heading (BBCH 5558) stages according to Meier (2001). A knapsack sprayer 'Garden 15' (Germany) was used for the spray application. Assessments of disease severity and incidence were carried out before the spray application of the bioproducts and 2-3 weeks after the application. A total of 25 randomly selected plants per each plot were assessed. Disease incidence and severity were estimated on three upper fully expanded leaves, later assessments were done on the remaining vegetating upper leaves according to the disease-affected leaf area in percentage, following the methodology approved by the EPPO standards (PP1/26(4), 1997).

The biological efficacy of the tested products was calculated according to Abbot's formula (Korol et al., 1990): $X=a-b / a \times 100$, where $X$ is biological efficacy of the tested product \%; $a$ is disease incidence or severity in the control, $\% ; b$ is disease incidence or severity in the treatment where the test products have been used, $\%$.

\section{Analysis of yield}

For the determination of winter wheat biometric indicators, the plant samples were uprooted before harvesting at the complete maturity stage $(\mathrm{BBCH}$ 89) from three replications of individual treatments from four different spots $0.25 \mathrm{~m}^{2}$ in size and were analysed.

Winter wheat grain quality indicators (protein, wet and dry gluten, sedimentation, falling number) were analysed at the LAMMC Agrochemical Research Laboratory according to the standard methods. One thousand grain weight was established using an Elmor C1 seed counter (Switzerland).

The research results were analysed by the ANOVA technique, the least significant difference $(P \leq 0.05)$ was estimated (Raudonius, 2017).

\section{Meteorological conditions}

2014 presented higher air temperature and a low rainfall level in May and June compared to the multiannual averages. In May 2014, the mean daily temperature was higher than the long-term average. The highest amount of rainfall $(22 \mathrm{~mm})$ fell in the second ten-day period. The mean monthly temperature of June was by $2.6^{\circ} \mathrm{C}$ higher than the long-term mean. The mean daily temperature of July was $19.6^{\circ} \mathrm{C}$, and the monthly amount of rainfall was $146 \mathrm{~mm}$.

In 2015, during the plant vegetation period (May-August), the sum of active temperatures was $2457.0^{\circ} \mathrm{C}$, the rainfall amounted to $173.0 \mathrm{~mm}$. The mean monthly temperature of May varied from 14.6 to $17.9^{\circ} \mathrm{C}$. In the first ten-day period of May, there was no rainfall, but in the second and third ten-day periods the rainfall amounted to 17.1 and $46.7 \mathrm{~mm}$. A dried period occurred in the second ten-day period of June. The air temperature in 
June was higher than the long-term average and varied within the $17.2-19.7^{\circ} \mathrm{C}$ range. July and $\mathrm{Au}-$ gust were characterised by a weak and very heavy drought.

The weather conditions during the cultivar development period were favourable for the evaluation of the main diseases and lodging resistance as well as the measurement of grain yield and quality stability.

\section{RESULTS AND DISCUSSION}

\section{The effect of the products on winter wheat seed germination and contamination with microscopic fungi}

Biokal 01 ir Fitokondi were found to increase seed vigour and germination. Biokal 01 had a greater positive effect on seed vigour, while Fitokondi on seed germination; however, both products did not have a significant effect on seed vigour and germination, only a trend was established, which suggests that winter wheat seed treatment with Biokal 01 and Fitokondi results in an increase in seed vigour and germination.

During the experimental years, fungal infection of winter wheat grain was relatively low: Fusarium spp. was identified in 2.0\%, Alternaria spp. in $20.0 \%$ and Penicillium spp. in $30.0 \%$ of the total tested samples (Table 1). Compared with the untreated control, the standard seed treater significantly decreased the fungal infection level on grain. Of all bioproducts tested, Fitokondi exhibited the highest efficacy against seed-borne fungi. The biological efficacy of this product against Fusarium and Alternaria spp. fungi was $50.0 \%$, against Penicillium spp. it was $20.0 \%$. Having treated the seed with Biokal 01, a statistically significant difference was obtained only against various other fungi, including Mucor spp., Aspergillus spp. and Mycelia sterilia, the biological efficacy of the product was 3.8; however, Biokal 01 was inefficient in reducing seed contamination with pathogenic Fusarium spp., and did not have any effect on the reduction of fungi of Alternaria and Penicillium genera either.

Bioproducts that contain pesticidal plant extracts influence the occurrence of causal agents of some diseases. The research has found that plants possessing pesticidal properties inhibit the development of fungi of Alternaria, Fusarium, Aspergillus, Botrytis genera (El-Assiuty et al., 2006; Fawzi et al., 2009). The bioproduct Fitokondi contains extracts of seven medicinal plant species, therefore it can be assumed that it reduced the wheat seed contamination more efficiently than Biokal 01.

In the laboratory experiment, where winter wheat was grown by the wet filter paper roll method, crown rot was identified on $84.0 \%$ of winter wheat seedlings, on $74.0 \%$ of roots and on $100 \%$ of seeds (Table 2). Due to the application of the bioproducts Biokal 01 and Fitokondi the severity of crown rots on the coleoptiles significantly decreased by $12.0-16.0 \%$; however, the biological efficacy of both products was low - 19.0 and $14.3 \%$, respectively. Biokal 01 and Fitokondi contain extracts of various plants, including Chelidonium majus, which inhibits the spread of pathogenic fungi Fusarium culmorum, F. graminearum and F. oxysporum and is characterised by antibacterial properties (Saglam, Arar, 2003; Pârvu et al., 2008).

In the control treatment, the average incidence of crown rot diseases on winter wheat roots was $74.0 \%$ and the disease severity was as low as $2.0 \%$. Biokal 01 gave a more effective protection of wheat roots against the causal agents of diseases

Table 1. The effect of products on the winter wheat cultivar 'Širvinta 1' seed contamination with fungi, 2014

\begin{tabular}{|c|c|c|c|c|c|c|c|c|}
\hline \multirow{3}{*}{ Products } & \multicolumn{8}{|c|}{ Seed affected by fungi, \% } \\
\hline & \multicolumn{2}{|c|}{ Fusarium spp. } & \multicolumn{2}{|c|}{ Alternaria spp. } & \multicolumn{2}{|c|}{ Penicillium spp. } & \multicolumn{2}{|c|}{ Other fungi } \\
\hline & 1 & 2 & 1 & 2 & 1 & 2 & 1 & 2 \\
\hline Untreated seeds & 2.0 & - & 20.0 & - & 30.0 & - & 37.0 & - \\
\hline Maxim Star $025 \mathrm{FS} 1 \mathrm{t} \mathrm{t}^{-1}$ & $0^{*}$ & 100 & $6.0^{*}$ & 70.0 & $5.0^{*}$ & 83.3 & $14.0^{*}$ & 62.0 \\
\hline Biokal $0110 \mathrm{lt}^{-1}$ & 2.0 & 0 & 21.0 & 0 & 33.0 & 0 & 23.0 & 38.0 \\
\hline Fitokondi $6 \mathrm{lt} \mathrm{t}^{-1}$ & 1.0 & 50.0 & $10.0^{*}$ & 50.0 & $24.0^{*}$ & 20.0 & $28.0^{\star}$ & 26.0 \\
\hline
\end{tabular}

1 is incidence, $\% ; 2$ is biological efficacy, $\%$; ${ }^{*}$ is significantly different from the control at $P \leq 0.05$. 
Table 2. The effect of the products on the incidence and severity of infection on winter wheat cultivar 'Širvinta 1' coleoptiles, roots and seeds in 2014

\begin{tabular}{c|c|c|c|c|c|c|cc}
\hline \multirow{2}{*}{ Products } & \multicolumn{3}{c}{ Coleoptiles } & \multicolumn{3}{c|}{ Roots } & \multicolumn{2}{c}{ Seeds } \\
\cline { 2 - 9 } & $\mathbf{1}$ & $\mathbf{2}$ & $\mathbf{3}$ & $\mathbf{1}$ & $\mathbf{2}$ & $\mathbf{3}$ & $\mathbf{1}$ & $\mathbf{3}$ \\
\hline Untreated seeds & 84.0 & 3.7 & - & 74.0 & 2.0 & - & 100 & - \\
\hline Maxim Star 025 FS 1 1 t & $28.0^{*}$ & $1.5^{*}$ & 67.0 & $22.0^{*}$ & 0.8 & 70.3 & $12.0^{*}$ & 88.0 \\
\hline Biokal 01 $10 \mathrm{t}^{-1}$ & $68.0^{*}$ & 3.4 & 19.0 & $20.0^{*}$ & 2.0 & 73.0 & 100 & 0 \\
\hline Fitokondi 6 $1 \mathrm{t} \mathrm{t}^{-1}$ & $72.0^{*}$ & 4.4 & 14.3 & $53.0^{*}$ & 3.2 & 28.4 & $76.0^{*}$ & 24.0 \\
\hline
\end{tabular}

1 is incidence, $\% ; 2$ is severity, $\% ; 3$ is biological efficacy, $\%{ }^{*}$ means significantly different from the control at $P \leq 0.05$.

compared to Fitokondi. The efficacy of Biokal 01 against crown rot diseases was $73.0 \%$, while that of the seed treater Maxim Star 025 FS 1 was $70.3 \%$. Based on the previous studies of the bioproducts in wet filter paper rolls (Gaurilčikienè et al., 2008), it can be assumed that Biokal 01 gives a more effective control of some Fusarium and Penicillium spp. causal agents for which wet filter rolls provide more favourable development conditions.

The tests of winter wheat seeds in wet filter paper rolls revealed that under the effect of Fitokondi, contamination with seed-borne fungi (Fusarium spp., Penicillium spp., Alternaria spp.) decreased by $24.0 \%$, compared with the control. However, the effect of Biokal 01 on the reduction of fungal contamination of seed did not stand out.

The effect of the bioproducts on the incidence of foliar fungal diseases in winter wheat crops

In the years of research, during the winter wheat tillering stage (BBCH 25-30) Septoria leaf blotch began to spread. The prevalence of Septoria leaf blotch in control fields was low at $2.2 \%$, the intensity at $1.3 \%$. The first symptoms of the disease are markedly influenced by the weather conditions - air temperature, moisture and light (Ponomarenko et al., 2011). The bioproducts Fitokondi and Biokal 01 have reduced the intensity of the disease very slightly $-0.1 \%$, compared to the control - non-essential. During the wheat booting stage (BBCH 40-45), the intensity of Septoria leaf blotch was $6.6 \%$. The Biokal 01 Septoria leaf blotch intensity did not decrease, compared to the control, bioproducts in sprayed fields, it increased by $0.3 \%$, respectively. Only Fitokondi wheat has a $0.4 \%$ reduction in intensity, but it did not differ significantly from the control. During the cereal flowering stage (BBCH 60-65), the intensity of Septoria leaf blotch on two upper wheat leaves reached $13.3 \%$. The bioproducts studied had no effect on limiting the development of Septoria leaf blotch. In Biokal 01 and Fitokondi-sprayed

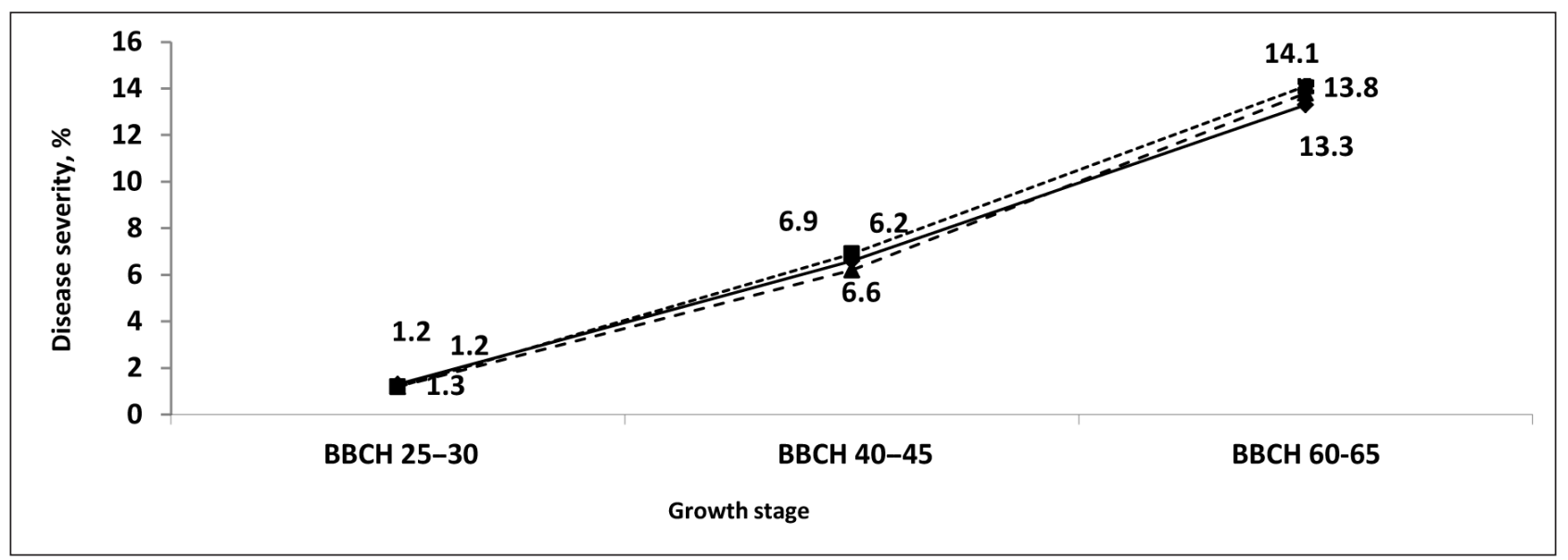

Fig. 1. Septoria leaf blotch severity in unsprayed (-), sprayed with Biokal $01(\ldots)$ and with Fitokondi (---) winter wheat cultivar 'Širvinta 1' treatments, 2014-2015 
wheat, the intensity of disease was slightly increased compared to the control, 0.8 and $0.5 \%$, respectively.

Winter wheat tan spot, caused by Pyrenophora tritici-repentis (Died.) Drechs. (anamorph: Drechslera tritici repentis (Died.) Shoemaker), is a widespread disease in winter and spring wheat crops. Tan spot is currently a more aggressive and less controlled disease than Septoria leaf blotch when wheat is continuously grown after wheat (Eurostat, 2017). Yield losses to tan spot may reach up to $50.0 \%$ (Ronis et al., 2006). The incidence of the disease on wheat leaves at the tillering stage (BBCH 25-30) was low, in the control treatment disease-affected plants accounted for up to $1.2 \%$. In the treatments spray-applied with Biokal 01 and Fitokondi, the disease severity was by $0.1 \%$ lower and insignificant compared with the control treatment (Fig. 2). At the wheat shooting stage (BBCH 40-45), the incidence of tan spot was not high due to the weather conditions which were not favourable for the occurrence of the disease. Under the conditions of a frequent alternation of wet and dry periods tan spot forms fewer spots on plants. This hap- pens due to the fact that during a dry period germinating conidia lose water and perish (Sah, 1991). A very negligible reduction (0.02\%) in tan spot severity was recorded under the effect of Fitokondi.

At the wheat shooting stage (BBCH 60-65), the $\tan$ spot severity on wheat leaves amounted to $15.0 \%$. The tested bioproducts did not have a positive effect on limiting the incidence of $\tan$ spot.

\section{The effect of the bioproducts on winter wheat biometric indicators and grain yield}

Biokal 01 and Fitokondi increased the number of productive stems $\mathrm{m}^{2}$, but no significant effect was identified compared with the control treatment (Table 3). The spray application of organically grown winter wheat with Biokal 01 and Fitokondi significantly increased the plant length by $6.1-6.6 \mathrm{~cm}$ or $6.5-6.9 \%$, the ear length by $0.6-$ $0.7 \mathrm{~cm}$ or $6.9-8.5 \%$, the grain number per ear by $3.5-4.02$ grains or $14.5-16.9 \%$, and the 1000 grain weight by $1.6-2.0 \mathrm{~g}$ or $4.4-5.6 \%$; however, the comparison of the effect of the two products did not reveal any significant differences between

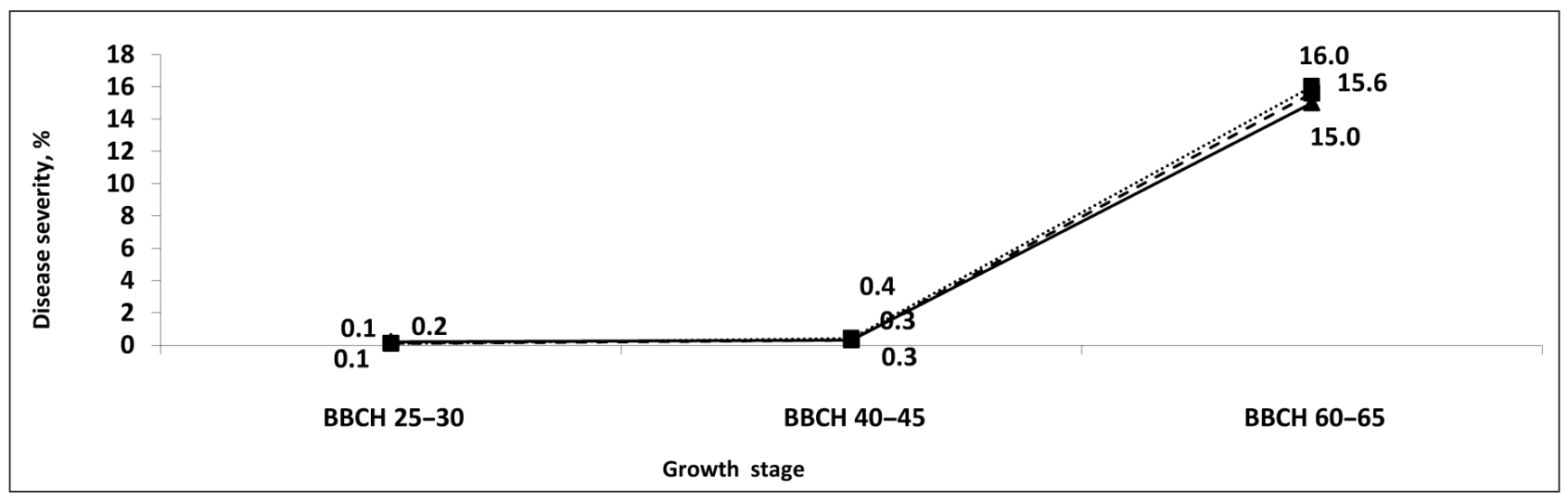

Fig. 2. Tan spot severity in unsprayed (-), sprayed with Biokal $01(\cdots)$ and with Fitokondi (---) winter wheat cultivar 'Širvinta 1' treatments, 2014-2015

Table 3. The effect of bioproducts on the biometric characteristics of winter wheat cultivar 'Širvinta 1', 2014-2015

\begin{tabular}{c|c|c|c|c|c|c}
\hline Bioproducts & $\begin{array}{c}\text { Number of } \\
\text { productive } \\
\text { stems, } \mathbf{~ m}^{-2}\end{array}$ & $\begin{array}{c}\text { Stem } \\
\text { height, } \\
\mathbf{c m}\end{array}$ & $\begin{array}{c}\text { Ear } \\
\text { length, } \\
\mathbf{c m}\end{array}$ & $\begin{array}{c}\text { Number of } \\
\text { grains per ear, } \\
\text { units }\end{array}$ & $\begin{array}{c}\text { Number of } \\
\text { productive stems } \\
\text { per plant, units }\end{array}$ & $\begin{array}{c}\mathbf{1 0 0 0} \\
\text { grain } \\
\text { weight, g }\end{array}$ \\
\hline Unsprayed & 371.7 & 94.6 & 7.4 & 23.8 & 1.4 & 36.4 \\
\hline Biokal $01101 \mathrm{ha}^{-1}$ & 385.7 & 101.2 & 8.1 & 27.8 & 1.5 & 38.4 \\
\hline Fitokondi $61 \mathrm{ha}^{-1}$ & 380.5 & 100.7 & 8.0 & 27.2 & 1.4 & 38.0 \\
\hline
\end{tabular}

Note: no differences, $P \leq 0.05$. 
the values of the above-presented indicators. Only a trend was established suggesting that the spray application with Biokal 01 exerted a greater effect than Fitokondi. These bioproducts also slightly increased the total number of productive stems per plant.

In the field trials, the bioproducts Biokal 01 and Fitokondi were found to significantly increase the grain yield of the organically grown winter wheat cultivar 'Širvinta 1' (Table 4). The grain yield was also influenced by the weather conditions during the wheat growing season. Under the effect of the bioproducts, the grain yield increased by on average $0.7-0.8 \mathrm{t} \mathrm{ha}^{-1}$ or $18.6-22.3 \%$. Biokal 01 gave a greater grain yield increase than Fitokondi; however, the difference was not significant. The tested bioproducts contain different amounts of an aqueous extract of biohumus. As a result, due to a greater nutrient content, Biokal 01 tended to increase grain yield more than Fitokondi. The previous research has proved the efficacy of Biokal 01 for organically grown agricultural crops (Pekarskas, 2008; Jablonskytè-Raščè et al., 2012).

The averaged data suggest that the biological products influenced the grain chemical composition. Under the effect of these products the grain protein content increased by $0.5-0.7$, the wet gluten content by $0.9-1.3$, and the dry gluten content by $0.5-0.7$ percentage points. The spray application of wheat crops with Biokal 01 significantly increased the protein, wet and dry gluten content compared with Fitokondi. This can be explained by the different nutrient content in the bioproducts. The research has established that the grain quality indicators were significantly influenced by the spray application of Biokal 01, under the effect of which the grain protein content and gluten content increased by 2.1 and
$2.6 \%$, respectively, compared with the control (Jablonskytė-Raščè et al., 2012). However, these products did not have a significant effect on the values of the sedimentation and falling number. A trend was determined that under the effect of Biokal 01 and Fitokondi the value of sedimentation increased and that of the falling number decreased.

\section{CONCLUSIONS}

1. Fitokondi exhibited the highest efficacy and protection of winter wheat grain against pathogens. Its biological efficacy against Fusarium and Alternaria spp. fungi amounted to $50.0 \%$, against Penicillium spp. to $20.0 \%$. Biokal 01 statistically significantly reduced seed contamination with Mucor spp. and Aspergillus spp.

2. The bioproducts tested by the filter paper roll method significantly reduced the incidence of crown rot diseases in the coleoptiles and roots of wheat seedlings; however, they did not exert any significant effect on the disease severity. Biokal 01 was most efficient in inhibiting the incidence of crown rot diseases in wheat coleoptiles and roots. Fitokondi significantly reduced seed contamination with microscopic fungi by $24.0 \%$.

3. The tested bioproducts did not significantly limit the incidence of Septoria leaf blotch and tan spot during the growing season.

4. Biokal 01 and Fitokondi significantly increased the wheat plant height and ear length, seed number per ear and 1000 grain weight.

5. Biokal 01 and Fitokondi significantly increased the winter wheat grain yield by $0.7-$ $0.8 \mathrm{tha}^{-1}$ or $18.6-22.3 \%$, and the content of protein by $0.5-0.7$, wet gluten by $0.9-1.3$ and dry gluten by $0.5-0.7$ percentage points in wheat grain.

Table 4. The effect of biological products on the winter wheat cultivar 'Širvinta 1' grain yield and chemical composition, 2014-2015

\begin{tabular}{c|c|c|c|c|c|c}
\hline Bioproducts & $\begin{array}{c}\text { Yield, } \\
\text { t ha }\end{array}$ & $\begin{array}{c}\text { Protein, } \\
\%\end{array}$ & $\begin{array}{c}\text { Wet gluten, } \\
\%\end{array}$ & $\begin{array}{c}\text { Dry gluten, } \\
\%\end{array}$ & $\begin{array}{c}\text { Sedimentation, } \\
\text { ml }\end{array}$ & $\begin{array}{c}\text { Falling } \\
\text { number, s }\end{array}$ \\
\hline Unsprayed & 3.5 & 10.0 & 19.0 & 6.0 & 28.4 & 231.8 \\
\hline Biokal 01 10 $1 \mathrm{ha}^{-1}$ & 4.33 & 10.7 & 20.3 & 6.6 & 30.9 & 227.8 \\
\hline Fitokondi $61 \mathrm{ha}^{-1}$ & 4.20 & 10.5 & 19.9 & 6.4 & 29.8 & 226.0 \\
\hline
\end{tabular}

Note: no differences, $P \leq 0.05$. 
However, Biokal 01 increased the grain protein, wet and dry gluten contents more than Fitokondi.

Received 13 February 2019 Accepted 26 April 2019

\section{REFERENCES}

1. Al-Askar A. A., Rashad Y. M. 2010. Efficacy of some plant extracts against Rhizoctonia solani on pea. Journal of Plant Protection Research. Vol. 50(3). P. 239-243.

2. Bhathal J. S., Loughman R., Speijers J. 2002. Yield reduction in wheat in relation to leaf disease from yellow (tan) spot and Septoria nodorum blotch. European Journal of Plant Pathology. Vol. 109. P. 435-443.

3. Bond W., Grundy A. C. 2001. Non-chemical weed management in organic farming systems. Weed Research. Vol. 41. P. 383-405.

4. Budzynski W. S., Jankowski K. J., Szemplinski W. 2003. Cultivar-related and agronomic conditions of rye yielding on good rye soil suitability complex. Part I: Yield and its relationship with the yield components. Agronomy. Vol. 6(1). P. 1-11.

5. El-Assiuty E. M., Bekheet F. M., Fahmy Z. M., Ismael A. M., El-Alfy T. S. M. 2006. Potentiality of some isolated compounds from Halfa Barr Cymbopogon proximus Stapf. against the toxigenic fungi Fusarium verticillioides and Aspergillus flavus. Egyptian Journal of Phytopathology. Vol. 34(2). P. 75-84.

6. EPPO Standards. Guidelines for the efficacy evaluation of plant protection products. Fungicide (Vol. 2. 197 p.). Paris, 1997.

7. Eurostat. 2017. Available at: http://ec.europa.eu/ eurostat/statistics-explained/index.php/Main_annual_crop

8. Fawzi E. M., Khalil A. A., Afifi A. F. 2009. Antifungal effect of some plant extracts on Alternaria alternata and Fusarium oxsysporum. African Journal of Biotechnology. Vol. 8(11). P. 2590-2597.

9. Finch M. R., Schulte-Geldermann E., Bruns C. 2006. Challenges to organic potato farming: disease and nutrient management. Potato Research. Vol. 49. P. 27-42.

10. Gaurilčikienė I., Supronienè S., Ronis A. 2008. The impact of the biological agent biojodis on the incidence of pathogenic fungi in winter wheat and spring barley. Žemdirbystè-Agriculture. Vol. 95(3). P. 406-414.
11. Jablonskytė-Raščè D., Maikštėnienė S., Cesevičienè J., Mankevičienè A. 2012. Ekologiškų trąšų ir bioaktyvatorių itaka paprastujų kviečių (Triticum aestivum L.) ir spelta kviečių (Triticum spelta L.) produktyvumui bei derliaus kokybei. Žemès ūkio mokslai. T. 19(1). P. 1-10.

12. Knittel H., Albert E. 2003. Düger und Düngung. Bergen/Dumme: Agrimedia. 217 p.

13. Korol A. L., Preičerzon V. A. 1990. Statisticheskaya otsenka biologicheskoi effektivnosti preparata s pomoshchyu EVM. Zashchita rastenii. Vol. 10. P. 22-23.

14. Leslie J. F., Summerell B. A. 2006. The Fusarium Laboratory Manual. Iowa, USA. 388 p.

15. Mathur S. B., Kongsdal O. 2003. Common Laboratory Seed Health Testing Methods for Detecting Fungi. Copenhagen. 425 p.

16. Meier U. 2001. Growth Stages of Mono- and Dicotyledonous Plants: BBCH - Monograph. 2nd ed. Berlin, Germany: Federal Biological Research Centre for Agriculture and Forestry. 158 p.

17. Pârvu M., Pârvu A. E., Crăciun C, Barbu-Tudoran L., Tămaş M. 2008. Antifungal activities of Chelidonium majus extract on Botrytis cinerea in vitro and ultrastructural changes in its conidia. Journal of Phytopathology. Vol. 156. P. 550-552.

18. Pekarskas J. 2008. Tręšimas ekologinès gamybos ükiuose. Kaunas. 189 p.

19. Ponomarenko A., Goodwin S. B., Kema G. H. J. 2011. Septoria tritici blotch (STB) of wheat. Plant Health Instructor. DOI: 10.1094/PHI-I-2011-0407-01.

20. Raudonius S. 2017. Application of statistics in plant and crop research: important issues. ŽemdirbystéAgriculture. Vol. 4(4). P. 377-382.

21. Ronis A., Semaškienė R. 2006. Development of tan spot (Pyrenophora tritici-repentis) in winter wheat under field conditions. Agronomy Research. Vol. 4. P. 331-334.

22. Saglam H., Arar G. 2003. Cytotoxic activity and quality control determinations on Chelidonium majus. Fitoterapia. Vol. 74. P. 127-129.

23. Sah D. N. 1991. Influence of interrupted leaf wetness duration and relative humidity on development of tan spot in wheat. Zeitschrift für Pflanzenkrankheiten und Pflanzenschutz. Vol. 101. P. 148-153.

24. Satton D., Fotergill A., Rimaldi M. 2001. Opredelitel patogennykh i uslovno patogennykh gribov. Moskva. $451 \mathrm{~s}$.

25. Sliesaravičius A., Pekarskas J., Rutkovienė V., Baranauskis K. 2006. Grain yield and disease resistance of winter cereal varieties and application of biological agent in organic agriculture. Agronomy Research. Vol. 4. P. 371-378. 
Jolanta Sinkevičienè, Juozas Pekarskas

\section{BIOLOGINIŲ PRODUKTŲ İTAKA EKOLOGIŠKAI AUGINTIEMS ŽIEMINIAMS KVIEČIAMS (TRITICUM AESTIVUM L.)}

\section{Santrauka}

Tyrimų tikslas - ištirti biologinių produktų Biokal 01 ir Fitokondi įtaką ekologiškų žieminių kviečių (Triticum aesti$v u m$ L.) veislès 'Širvinta 1' grūdų priešsèjiniam daigumui ir užterštumui mikroskopiniais grybais, kviečių lapų ligų plitimui vegetacijos metu, biometriniams rodikliams ir derliaus kokybei. Laboratoriniais tyrimais nustatyta, kad biologiniai produktai neturèjo esminès įtakos sèklų dygimo energijai ir daigumui. Veiksmingiausiai kviečius nuo patogenų ant PDA terpès apsaugojo Fitokondi, kurio biologinis efektyvumas nuo Fusarium ir Alternaria spp. grybų buvo 50,0 \%, nuo Penicillium spp. - 20,0 \%. Biokal 01 statistiškai patikimai sumažino grūdų užterštumą kitais grybais
(Mucor spp., Aspergillus spp. ir kt.). Filtro popieriaus rulonų metodu tirtų bioproduktų poveikis daigų koleoptilèse ir šaknyse pašaknio ligų plitimą sumažino iš esmès, ligų intensyvumui esminès ịtakos nenustatyta. Biokal 01 efektyviausiai apribojo pašaknio ligų išplitimą kviečių koleoptilèse ir šaknyse. Dẻl Fitokondi poveikio sẻklos užterštumas mikroskopiniais grybais sumažèjo iš esmès. Lauko tyrimų metu biologiniai produktai neturejo esminès įtakos lapų septoriozès (Mycosphaerella graminicola) ir kviečiuc dryžligès (Helminthosporium tritici-repentis Died.) plitimui. Dèl Biokal 01 ir Fitokondi iš esmès padidèjo augalų ir varpu ilgis, grūdų skaičius varpoje ir 1000 grūdų masè, 0,66-0,79 tha $^{-1}$ arba 18,64-22,32 \% padidejjo grūdų derlius, padaugèjo baltymų, šlapiojo glitimo ir sausojo glitimo. Dèl Biokal 01, palyginti su Fitokondi, grūduose iš esmès padaugejo baltymų, šlapiojo ir sausojo glitimo.

Raktažodžiai: kviečiai, bioproduktai, ekologinis ūkininkavimas, mikroskopiniai grybai, derlius 